\title{
DESIGEN AND SETUP A BAFFLED FACULTATIVE POND FOR DAIRY WASTEWATER TREATMENT
}

\author{
FARAG, H. A. ${ }^{1}$, H. S. MEHAWED ${ }^{1}$ and O. M. GUERO ${ }^{2}$ \\ 1. Agricultural Engineering Research Institute (AEnRI), Egypt \\ 2. Centre for Geological and Mining Research, (Cell SIGMINES) Niamey, Niger
}

(Manuscript received 10 Decembre 2013)

\begin{abstract}
This study is a laboratory work to use a baffled stabilization pond for dairy wastewater treatment. The ponds consist of a storage tank, a baffled facultative pond and an effluent tank. The dairy wastewater was obtained from dairy research program, National Animal Production Research Project (NAPRP), Abdou Moumouni Dioffo_University located in Niger. The pond was loaded for ten different detention periods namely: Three, Six, Nine, Twelve, Fifteen, Eighteen, Twenty one, Twenty four, Twenty seven, and Thirty days. The parameters investigated were the biochemical oxygen demand (BOD), Chemical oxygen Demand (COD), phosphate, total solids, nitrate - nitrogen, $\mathrm{pH}$, Dissolved oxygen (DO), Alkalinity , Bacterial count and chlorophyll a. The results which were the mean of six replicates showed that the baffled facultative pond performed good methods in the removal of the pollutants. The BOD removal efficiency in the baffled facultative pond were $6.45 \%, 32.26 \%, 41.94 \%, 61.29 \%, 70.97 \%, 75.48 \%$, $82.58 \%, 89.68 \%, 94.19 \%$ and $96.13 \%$ for the $3,6,9,12,15,18$, $21,24,27$ and 30 days detention period respectively. The baffled facultative pond was able to eliminate $99.98 \%$ of the total wastes. The $\mathrm{pH}$ value was between 6.8 and 7.23 which is suitable for bacteria growth $(6.5-8.5)$. It was also observed that a linear relationship existed between the $B O D$ and $C O D$, and between the $\mathrm{BOD}$ and the DO of the Dairy wastewater.
\end{abstract}

\section{INTRODUCTION}

In the last half of the twentieth century, the impact of increasing population and industrialization cause a massif contamination of air, water, soil and animals of the ecosystem. Ultimately this represents a threat to survival of human race. Water is the main transporter of pollutants especially those from domestic and industrial sources. Wastewater from both sources differs in quality and quantity, and in their effects on public health. Industrial wastewaters are of different types (e.g. Brewery wastewater, Textile wastewater and Dairy wastewater etc) (Kareen, 2002). Ozoukwu (2004) mentioned that, the most effluent after treatment is discharged into a river or other forms of water body. Therefore it is necessary that the degree of treatment is to extent that the effluent would not result in the pollution of the receiving water body. If the receiving water body is a river, the strength of the effluent should not be as 
much as to make the river dangerous for the future use of another community downstream. In many arid and semi-arid areas of the world, large scale reuse of sewage effluents is necessary because of the water shortages which result from increasing population and agricultural demand. The health risks associated with human waste reuse have been widely examined over the past twenty years and many epidemiological studies have shown demonstrable health effect from wastewater reuse (Horan, 2003). So due to these reasons there is a need to treat wastewater. In modem societies, proper management of wastewaters is a necessity not an option. Current practice requires that wastewaters are given adequate treatment to meet effluent standards set by environmental protection authorities.

According to Ramadan and Ponce (2006) a properly designed anaerobic pond can achieve 60 to $85 \%$ BOD removal at temperatures higher than $20{ }^{\circ} \mathrm{C}$. A hydraulic retention time of one day is sufficient for wastewater with BOD of up to $300 \mathrm{mg} / \mathrm{l}$, at temperature higher than $20^{\circ} \mathrm{C}$. The odor problems can be minimized if the sulfate concentration of the pond is less than $500 \mathrm{mg} / \mathrm{l}$.

Najafpour, et al. (2008) stated that, an up flow anaerobic sludge-fixed film (UASFF) reactor is a granular sludge bioreactor that was used for the rapid biological conversion of organic matter to biogas with the aids of aggregated microbial consortium. The major problem associated with the conventional UASB reactor is the long duration for start up period. In this study, UASFF bioreactor with tubular flow behavior was developed in order to shorten the start-up period at low HRT. The reactor was operated at $36^{\circ} \mathrm{C}$ and HRT of 36 and $48 \mathrm{~h}$. The organic loading rate was gradually increased from 7.9 to $45.42 \mathrm{~g} \mathrm{COD/l.d.} \mathrm{In} \mathrm{this} \mathrm{research} \mathrm{flocculated} \mathrm{granular}$ sludge was built in a short period of 4 to 5 days. The core of the granular sludge was developed within 20 days. At HRT $48 \mathrm{~h}$ and temperature $36^{\circ} \mathrm{C}$, the COD removal rate and lactose conversion of 97.5 and 98 percent were obtained, respectively. The use of an internal up flow anaerobic fixed film section caused the flocculated biomass was trapped in the sludge blanket and the delivery of biogas was easily performed.

Varon and Mara (2010) reported, treatment normally adopted for wastewater includes;

Physical processes; Screening, Mixing, Comminution, Sedimentation, Filtration.

Chemical processes; Precipitation, Adsorption, Disinfection, Gas transfer, Coagulation, $\mathrm{PH}$ adjustment, Ion exchange.

Biological processes include; The activated sludge process, Trickling filter (or Bio filtration process), Waste stabilization pond system, Oxidation ditch, Aerated lagoon The biological treatment processes are of two major classes attached and suspended growth processes. The waste stabilization pond (w.s.p) technology is the suspended 
growth class. Also they defined the stabilization pond as it is a relatively shallow body of wastewater contained in an earthen man made basin into which wastewater flows, and from which after a certain retention time, a well treated effluent is discharged. The activity in a stabilization pond is a complex symbiosis of bacteria and algae, which stabilize the waste and reduces the number of pathogen micro-organisms. The stabilization pond has become a wastewater treatment method of first choice in most part of the tropical region of the world because it is cheap and easy to maintain and operate, highly sustainable and requires only solar energy for operation.

Mara, et al. (2004) stated that the anaerobic waste stabilization ponds are usually between 2 and $5 \mathrm{~m}$ deep which designed to receive high organic loadings that are completely devoid of dissolved oxygen. The ponds can receive as high as $100 \mathrm{~g}$ $\mathrm{BOD} / \mathrm{m} 3 / \mathrm{d}$. and mostly used to pre-treat strong wastes which have a high solid content. The solid settles to the bottom of the pond where they are digested anaerobically. The partially clarified supernatant liquor is discharged into a facultative pond for further treatment.

This study aims to investigate the treatment of dairy waste water by means of baffled stabilization ponds. The dairy research program at the National Animal Production Research Institute (NAPRI) ABU Zaria, was the source of the waste used in this study. The project focused on the waste water from yoghurt product and design of baffled stabilization ponds for the treatment of these wastewaters.

\section{MATERIALS AND METHODS}

The concept behind the project is to design of baffled stabilization ponds to improve the effluent quality from the dairy unit at (NAPRP). The research work aims to establish an empirical design for baffled facultative waste stabilization ponds based on the relationship between effluent quality and baffled spacing. The major limitation in this study was the project funded allows constructing one pond only.

\section{Materials}

The experimental set up consisting of a storage tank, baffled facultative pond. The storage tank was made of galvanized iron and measured $100 \mathrm{~cm} * 100 \mathrm{~cm} * 100 \mathrm{~cm}$, the baffled facultative pond was made of Perspex glass and has a working capacity of 500 liters. Light were provided for the baffled facultative pond by four 40 watts florescent bulbs each for the maturation ponds, all located $20 \mathrm{~cm}$ above the liquid surface. The baffled facultative pond supplied by a manual agitation system to turn the waste water twice per day. The tanks were connected in series and arranged to allow a gravity flow. Rubber tubes were used to connect the ponds while adjustable 
clips were used to regulate the flow system. The arrangement of the inflow into the facultative pond was such that the sediment at the bottom of the facultative pond was not disturbed. The experiment set up is shown in Fig.1. The daily waste was used as substrate. It was collected from the Dairy National Animal Production Research Project (NAPRP), Abdou Moumouni Dioffo_University located in Niger.

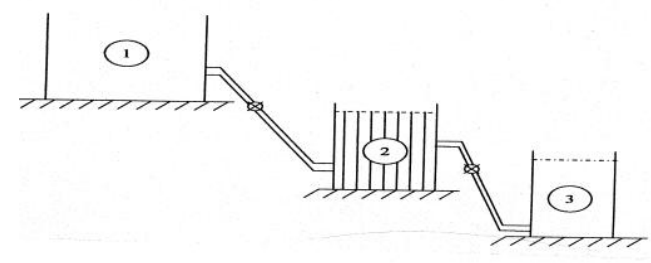

1- Influent Tank

2- Baffled Facultative Tank

3- Effluent Tank

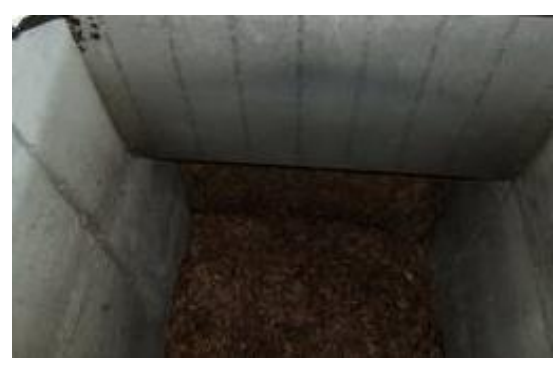

Fig.1. The experiments set up

\section{Design parameters:-}

There are basically four approaches to the design of waste stabilization ponds

1) Loading rate approach, facultative ponds are designed on the basis of surface loading rate

2) Temperatures, as the mean ambient temperature in the coolest months.

3) Net evaporative rate

4) Flow, (the suitable value is $80 \%$ of the water consumption)

5) The determined or the estimated BOD

The design of the baffled facultative pond is the similar of the facultative ponds without baffled. The detention period in the baffled facultative is higher than the detention period in the UN - baffled ponds. This due to the longer travel distance caused by the baffles which greater the redaction rate. The design equations based on these study is given by the following expressions.

$$
\frac{L_{e}}{L_{i}}=\frac{1}{1+K T}
$$


Where:

Le: effluent BOD $(\mathrm{mg} / \mathrm{L})$

Li: influent BOD $(\mathrm{mg} / \mathrm{L})$

K: reaction rate constant ( $1 /$ day)

T: detention time (day)

The $K$ values vary with the temperatures $(T)$ of the pond and it is determine by equation: $\mathrm{K}=\mathrm{K}_{20} * \mathrm{C} *(\mathrm{~T}-20)$

Where:

$\mathrm{K} 20$ is the reaction rate constant at $20^{\circ} \mathrm{C}$ and it ranged from 0.2 to 0.4 day.

C: Temperature correction factor (1.05)

The mid- depth area(A) which is the surface and base areas should be if the pond had vertical sides given by;

$A=\frac{Q^{*} T}{D}$

Where:

Q: volumetric flow rate $\mathrm{m}^{3} /$ day

D: Pond depth (1 to $1.5 \mathrm{~m}$ )

Then;

$$
A=\frac{Q}{D K}\left(\frac{L i}{L e}-1\right)
$$

- The Le should be ranged from 50 to $70 \mathrm{mg} / \mathrm{L}$ with the pond depth 1 to $1.5 \mathrm{~m}$.

- According to the previous equations the constructed facultative pond specification was as shown in Table (1).

Table 1. Facultative pond specification

\begin{tabular}{|c|c|c|c|c|}
\hline Parameters & Length L & Width B & Depth D & Baffle spacing \\
\hline Dimensions in cm & 200 & 100 & 25 & 20 \\
\hline
\end{tabular}

\section{Sample Site}

Previous survey conducted in this study area shows that the environment is free from dust and insects. The walls are covered with tiles and mosquito nets are also provided to prevent insects from entering.

The processing room consists of:
1) Heating section
2) Cooling section
3) Cold store
4) Sink for washing
5) Packaging section
6) Gutters are built to run through the floor slabs to allow flow of wastewaters into the suck away.


Milk for dairy is usually collected from farm located some few kilometers from the dairy. These are about 15 lactating animals in the farm which produce an average of 300 liters of milk per day. Milking is done twice a day (morning and evenings). The rest of the milk used is gotten from outside collections. They produce between 70 to 100 liters waste water per day. Production is carried out once every day throughout the week and it last between 9 am to $2 \mathrm{pm}$.

\section{Methods}

Samples are usually collected by trapping waste water in the sink during production, and then collected after production. The waste water is first mixed properly before collecting so that the particles that have settle at the bottom of the sink will be evenly distributed throughout the waste water. During the initial start up of the experiment, the facultative pond was filled with 10 liters of raw sewage. The content of the pond was thoroughly mixed and left for one week for algae suspension to develop in the pond. The test run of experiment was carried out under batch flow conditions. The daily wastewater was admitted by gravity into the baffled facultative pond from the storage tank at average flow rate of 16 liters per day providing a detention period of 9 days. The effluent from the baffled facultative pond was admitted by gravity into the effluent tank at the same flow rate. The influent and effluent of the ponds were analyzed for the following parameters accordance with the standard methods of the American Public Health Association (APHA) in an average room temperature of 21 degree $C$.
1) Biochemical oxygen demand
6) $\mathrm{pH}$
2) Chemical oxygen demand
7) Alkalinity
3) Phosphate
8) Dissolved oxygen
4) Nitrate - nitrogen
9) Bacteria count
5) Total solids
10) Chlorophyll "a

The performance of the unit was evaluated by the one to two days analysis of the influent and the corresponding effluent samples. All the measurements were carried out according to the standard methods.

\section{Determination of $\mathbf{p H}$}

The $\mathrm{pH}$ of the sample is carried out as specified in the standards method (APHA, 1985) the $\mathrm{pH}$ meter was accurate using buffer solution with different $\mathrm{pH}$.

\section{Determination of Dissolved Oxygen (DO)}

The quantity of dissolved oxygen of the sample is carried out using titration method as specified in the standard method. The sample is collected in a $250-300 \mathrm{ml}$ bottle and $2 \mathrm{ml}$ of manganese solution were added. As reagent, $2 \mathrm{ml}$ of alkali - iodide - 
acid was added well below the surface of the liquid. Then the bottle was shaking mechanically.

Then when settling has produced clear supernatant, $2 \mathrm{ml} \mathrm{of} \mathrm{H}_{2} \mathrm{SO}_{4}$ were added and re-stopper again and mix by gentle inversion. $200 \mathrm{ml}$ were removed for titration, and titrated with sodium hyposulfite to a pale straw color. $2 \mathrm{mI}$ of starch solution was added, and the sample was then titrated to the first disappearance of the blue color. The D.O is equal to the quantity of titrate used.

\section{Determination of total Dissolved Solids (TDS)}

Samples analysis for total and dissolved solids were evaporated and filtered respectively as specified in the standard method. Transfer $100 \mathrm{ml}$ of the sample poured into an evaporating dish that is already on the water bath to dry it at 105 degrees.

TDS $(\mathrm{mg} / \mathrm{I})=($ final- initial $) * 1000 * 1000 / \mathrm{ml}$ of sample

Where initial = weight of dish empty and, Final $=$ weight of dish + weight of TDS

\section{Determination of Phosphates}

The amount of phosphate is carried out as specified in the standard method. The sample is acidified with a strong acid solution, boiled gently for at least $90 \mathrm{mn}$, cooled and then neutralized to testing for phosphate. The amount of polyphosphate is obtained by subtracting the measured orthophosphate concentration in the sample from the quantity of total inorganic phosphate.

\section{Determination of Nitrogen -Nitrate}

The nitrogen-nitrate of the sample was carried out as specified in the standard method.

Neutralize the clarified sample to ph 7.0, and then $100 \mathrm{ml}$ of the sample putted in a beaker and evaporate to dryness on a water bath. Dissolve the residue using glass rod with $2 \mathrm{ml}$ phenol acid reagent. Dilute and transfer to Nester's tubes. $6 \mathrm{ml}$ of ammonium solution added. Read the color developed and calculate and estimate the nitrate concentration by comparing the reading with a standard curve.

\section{Determination of (BOD)}

The BOD of the sample was carried out as specified in the standard method. Prepare seeded dilution water, calculate dilution required, dilute sample with seeded dilution water in 21 volumetric flasks, transfer to numbered BOD bottles ( 4 bottles for each dilution), incubate the bottles for 5 days and determine residual dissolved oxygen after incubation period. 


\section{Determination of (COD)}

The COD of the sample was carried out as specified in the standard method.

1., a) Put $400 \mathrm{ml} \mathrm{H} 2 \mathrm{SO} 4$ in a refluxing flask.

b) Add $20 \mathrm{ml}$ of sample diluted to $20 \mathrm{ml}$ with distilled water and mix.

c) Add IOml standard K2Cr207 solution.

d) Attach the flask to the reflux condenser.

e) Add slowly $30 \mathrm{mI}$ concentrated $\mathrm{H} 2 \mathrm{SO} 4$ through the open end of the condenser, mixing thoroughly while adding the / acid.

2., a) Reflux the mixture for I hr.

b) Cool and then wash the condenser with about $25 \mathrm{ml}$ of distilled water.

3., a) dilute the mixture to about $150 \mathrm{ml}$ with distilled water and cool to room temperature.

b) Add 3 drops of ferrous indicator.

4., Titrate with Fe (NI4) $)_{2}(\mathrm{SO4})$ taking as the end point the sharp color change from blue-green to brown.

5., Reflux in the same manner a blank consisting of $20 \mathrm{ml}$ distilled water together with the reagents.

\section{Calculation}

$\mathrm{Mg} / \mathrm{l} \mathrm{COD}=(\mathrm{a}-\mathrm{b}) \mathrm{N} * 8000 / \mathrm{ml}$ of sample

$\mathrm{a}=\mathrm{ml} \mathrm{Fe}\left(\mathrm{SO}_{4}\right) 2$ used for blank

$\mathrm{b}=\mathrm{ml} \mathrm{Fe}\left(\mathrm{NH}_{4}\right)(\mathrm{SO} 4)_{2}$ used for sample

$\mathrm{N}$ : normality of $\mathrm{Fe}\left(\mathrm{NH}_{2}\right)\left(\mathrm{SO}_{2}\right)_{2}$

- Determination of bacterial count and Chlorophyll A and Alkalinity in water were carried out as specified in the APHA, standard method.

\section{RESULTS AND DISCUSSION}

\section{Organic removal}

Table (2) shows BOD, COD, DO and concentration of the wastewater for the $3,6,9,12,15,18,21,24,27$ and 30 day's detention period

\section{BOD and COD:-}

Table 2 shows the BOD and COD results of the stabilized effluent. BOD Irepresents the amount of oxygen required for the biological decomposition of the organic matter in sewage. In conjunction with BOD test, the COD is helpful in indicating the toxic condition and the presence of biological resistant organics substances. In COD determination, organics are converted to carbon dioxide and water whether or not the substance can be biologica1ly assimilated. Hence, COD 
values are usually higher than BOD values. So, it can be observed from the values that the raw water had a low BOD values compared to the COD values. The baffled facultative pond has BOD removal efficiency of $6.45 \%, 32.265,41.94 \%, 61.29 \%$, $70.97 \%, 75.48 \%, 82.58 \%, 89.68 \%, 94.195$ and $96.13 \%$ for $3,6,9,12,15,18,21$, 24,27 and 30 days detention periods respectively. It appears that increasing the detention period produces much better quality effluent. The COD decreases with increase in detention period. From the results COD values varies from $572 \mathrm{mg} / \mathrm{l}$ in the influent to $256 \mathrm{mgll}, 200 \mathrm{mg} / \mathrm{I}, 151 \mathrm{mg} / \mathrm{l}, 112 \mathrm{mg} / \mathrm{l}, 86 \mathrm{mg} / \mathrm{l}, 62 \mathrm{mg} / \mathrm{l}, 46 \mathrm{mg} / \mathrm{l}, 38$ $\mathrm{mg} / \mathrm{l}, 26 \mathrm{mg} / \mathrm{l}$ and 23mgll for 3, 6, 9, 12, 15, 18, 21, 24, 27 and 30 days detention periods respectively. The overall percentage removal is $55.24 \%, 65.03 \%, 73.600 .10$, $80.42 \%, 84.97 \%, 89.165,91.96 \%, 93.36 \%, 95.45 \%$ and $96.12 \%$ for $3,6,9,12,15$, $18,21,24,27$ and 30 days detention periods respectively.

Table 2. Organic removal

\begin{tabular}{|l|c|c|l|l|l|l|l|}
\hline $\begin{array}{c}\text { Detention } \\
\text { time } \\
\text { (days) }\end{array}$ & $\begin{array}{c}\text { BOD } \\
(\mathrm{mg} / \mathrm{L})\end{array}$ & $\begin{array}{c}\text { Removed } \\
(\%)\end{array}$ & $\begin{array}{c}\text { COD } \\
(\mathrm{mg} / \mathrm{L})\end{array}$ & $\begin{array}{c}\text { Removed } \\
(\%)\end{array}$ & $\begin{array}{c}\text { DO } \\
(\mathrm{mg} / \mathrm{L})\end{array}$ & COD/BOD & BOD/DO \\
\hline Effluent & 310 & $0 \%$ & 572 & $0 \%$ & 2.4 & 1.68 & 129.2 \\
\hline 3days & 290 & $6.45 \%$ & 256 & $55.24 \%$ & 2.3 & 0.88 & 126.1 \\
\hline 6days & 210 & $32.26 \%$ & 200 & $65.03 \%$ & 2.2 & 0.91 & 95.5 \\
\hline 9days & 180 & $41.94 \%$ & 151 & $73.60 \%$ & 2.3 & 0.87 & 78.2 \\
\hline 12days & 120 & $61.29 \%$ & 112 & $80.42 \%$ & 1.7 & 0.92 & 70.6 \\
\hline 15days & 90 & $70.97 \%$ & 86 & $84: 97 \%$ & 1.5 & 0.91 & 60.0 \\
\hline 18days & 76 & $75.48 \%$ & 62 & $89.16 \%$ & 1.2 & 0.88 & 63.33 \\
\hline 21days & 54 & $82.58 \%$ & 46 & $91.96 \%$ & 1.1 & 0.87 & 49.1 \\
\hline 24days & 32 & $89.68 \%$ & 38 & $93.96 \%$ & 0.4 & 1.65 & 80.0 \\
\hline 27days & 18 & $94.19 \%$ & 26 & $95.45 \%$ & 1.1 & 1.62 & 16.4 \\
\hline 30days & 12 & $96.13 \%$ & 23 & $96.12 \%$ & 2.1 & 1.67 & 5.7 \\
\hline
\end{tabular}

\section{Relationship between COD and BOD}

Table 2 shows the relationship between COD and BOD. It can be observed that the ratio of $\mathrm{COD}$ to $\mathrm{BOD}$ for different detention periods is very close. This means that there is a linear relationship between BOD and COD. Biochemical Oxygen Demand is linearly related to the Chemical Oxygen Demand. (Nwigwe, 2002)

\section{Dissolved Oxygen (DO)}

Table 2 shows the Dissolved Oxygen content of the pond at different detention periods. The Dissolved Oxygen reduction in the baffled facultative pond is due to the fact that at high organic loading, more Dissolved Oxygen utilization is expected for oxidation of organic matter in order to supply every energy required for photosynthesis. BOD and COD stabilization is more in the baffled facultative pond, this explain why the Dissolved Oxygen is low in the baff1ed facultative pond. Dissolved Oxygen reduces with increase in the organic loading. It could be seen that the ratio of $B O D$ to $D O$ is reducing for different detention periods. It shows that as BOD reduces 
in the pond; DO also reduce because of the organic loading which is becoming high with increase of the detention period. It can be observed that as the detention period increases, the BOD and the DO decrease. The calculated BOD/DO ratios are 129.17, $126.10,95.45,78.26,70.59,60.00,63.3,49.10,80.00,16.36$ and 5.71 for $0,3,6,9$, $12,15,18,21,24,27$ and 30 days detention period respectively. From the above results, it can be observed that there is a linear relationship between the BOD and the DO of the Dairy wastewater. It means that the Biochemical Oxygen Demand is linearly related to the Dissolved Oxygen.

\section{Phosphate removal}

The results represented on Table (3) seen that a reduction in the phosphate concentration is observed. The phosphate concentration reduces with increase in the detention period. The percentage removal is $54.70 \%, 59.83 \%, 73.50 \%, 76.92 \%$, $84.030 / 0,88.60 \%, 90.85 \%, 93.67 \%, 96.000 / 0$ and $97.67 \%$ for $3,6,9,12,15,18,21$, 24,27 and 30 days detention periods respectively. The removal is efficient in the baff1ed facultative pond the overall removal is $97.67 \%$.

Table 3. Phosphate results (stabilizes effluent values)

\begin{tabular}{|c|c|c|c|c|c|c|c|c|c|c|c|}
\hline $\begin{array}{c}\text { Detention } \\
\text { time (days) }\end{array}$ & Influent & $\begin{array}{c}3 \\
\text { days }\end{array}$ & $\begin{array}{c}6 \\
\text { days }\end{array}$ & $\begin{array}{c}9 \\
\text { days }\end{array}$ & $\begin{array}{c}12 \\
\text { days }\end{array}$ & $\begin{array}{c}15 \\
\text { days }\end{array}$ & $\begin{array}{c}18 \\
\text { days }\end{array}$ & $\begin{array}{c}21 \\
\text { days }\end{array}$ & $\begin{array}{c}24 \\
\text { days }\end{array}$ & $\begin{array}{c}27 \\
\text { days }\end{array}$ & $\begin{array}{c}30 \\
\text { days }\end{array}$ \\
\hline $\begin{array}{c}\text { Phosphate } \\
(\mathrm{mg} / \mathrm{l})\end{array}$ & 11.7 & 5.3 & 4.7 & 3.1 & 2.7 & 1.8 & 1.4 & 1.1 & 0.72 & 0.39 & 0.35 \\
\hline $\begin{array}{c}\% \text { removed } \\
(\%)\end{array}$ & $0 \%$ & $\begin{array}{c}54.7 \\
\%\end{array}$ & $\begin{array}{c}59.83 \\
\%\end{array}$ & $\begin{array}{c}73.50 \\
\%\end{array}$ & $\begin{array}{c}76.92 \\
\%\end{array}$ & $\begin{array}{c}84.03 \\
\%\end{array}$ & $\begin{array}{c}88.60 \\
\%\end{array}$ & $\begin{array}{c}90.85 \\
\%\end{array}$ & $\begin{array}{c}93.67 \\
\%\end{array}$ & $\begin{array}{c}96.00 \\
\%\end{array}$ & $\begin{array}{c}97.67 \\
\%\end{array}$ \\
\hline
\end{tabular}

\section{Nitrate - Nitrogen removal}

Table 4 shows the Nitrate-Nitrogen concentration and percentage removal at detention periods.

Table 4. Nitrate-Nitrogen results (stabilized eff1uent values).

\begin{tabular}{|c|c|c|c|c|c|c|c|c|c|c|c|}
\hline $\begin{array}{c}\text { Detention } \\
\text { time(day) }\end{array}$ & Influent & $\begin{array}{c}3 \\
\text { days }\end{array}$ & $\begin{array}{c}6 \\
\text { days }\end{array}$ & $\begin{array}{c}9 \\
\text { days }\end{array}$ & $\begin{array}{c}12 \\
\text { days }\end{array}$ & $\begin{array}{c}15 \\
\text { days }\end{array}$ & $\begin{array}{c}18 \\
\text { days }\end{array}$ & $\begin{array}{c}21 \\
\text { days }\end{array}$ & $\begin{array}{c}24 \\
\text { days }\end{array}$ & $\begin{array}{c}27 \\
\text { days }\end{array}$ & $\begin{array}{c}30 \\
\text { days }\end{array}$ \\
\hline $\begin{array}{c}\text { Nitrate- } \\
\text { Nitrogen } \\
(\mathrm{mg} / \mathrm{l})\end{array}$ & 41 & 37 & 21 & 17 & 11 & 9.5 & 5.3 & 2.8 & 1.9 & 0.92 & 0.81 \\
\hline $\begin{array}{c}\% \text { removed } \\
(\%)\end{array}$ & $0 \%$ & $\begin{array}{c}9.76 \\
\%\end{array}$ & $\begin{array}{c}48.78 \\
\%\end{array}$ & $58.54 \%$ & $73.17 \%$ & $76.83 \%$ & $87.07 \%$ & $93.17 \%$ & $95.37 \%$ & $97.76 \%$ & $98.23 \%$ \\
\hline
\end{tabular}

The results indicated that, shows stabilized results of Nitrate-Nitrogen $(\mathrm{mg} / \mathrm{l})$.

The results show that the average influent value of Nitrate-Nitrogen is $41 \mathrm{mg} / \mathrm{l}$. The baffled facultative pond has a percentage removal of $9.76 \%, 48.78 \%, 58.54 \%$, $73.17 \%, 76.83 \%, 87.07 \%, 93.17 \%, 95.375 \%, 97.76 \%$ and $98.23 \%$ for $3,6,9,12$, $15,18,21,24,27$ and 30 days detention periods respectively. From the results, it can be seen that the Nitrate-Nitrogen concentration reduces more in the baft1ed facultative pond with increase in the detention period. 


\section{Total Dissolved Solids (TDS) Removal}

Table 5 shows the concentration of Total Dissolved Solids of the effluent samples and the percentage removal at different detention periods includes all manners of solids that may be present in the wastewater.

Table 5. Total Dissolved Solids results (stabilized effluent values)

\begin{tabular}{|c|c|c|c|c|c|c|c|c|c|c|c|}
\hline $\begin{array}{c}\text { Detention } \\
\text { Time (days) }\end{array}$ & Influent & $\begin{array}{c}3 \\
\text { days }\end{array}$ & $\begin{array}{c}6 \\
\text { days }\end{array}$ & $\begin{array}{c}9 \\
\text { days }\end{array}$ & $\begin{array}{c}12 \\
\text { days }\end{array}$ & $\begin{array}{c}15 \\
\text { days }\end{array}$ & $\begin{array}{c}18 \\
\text { days }\end{array}$ & $\begin{array}{c}21 \\
\text { days }\end{array}$ & $\begin{array}{c}24 \\
\text { days }\end{array}$ & $\begin{array}{c}27 \\
\text { days }\end{array}$ & $\begin{array}{c}30 \\
\text { days }\end{array}$ \\
\hline $\begin{array}{c}\text { TDS } \\
\text { concentration }\end{array}$ & 508 & 520 & 530 & 610 & 500 & 402 & 220 & 178 & 82 & 71 & 56 \\
\hline $\begin{array}{c}\% \text { removal } \\
(\%)\end{array}$ & $0 \%$ & - & - & - & $1.57 \%$ & $20.08 \%$ & $56.69 \%$ & $64.96 \%$ & $83.86 \%$ & $86.02 \%$ & $88.98 \%$ \\
\hline
\end{tabular}

Table 5 shows the results of the stabilized effluent for the Total Dissolved Solids contents. The results indicated that, the solids contents in the baffled facultative pond is high than the one in the effluent for $0,3,6$ and 9 days detention periods, rising from $508 \mathrm{mg} / 1$ in the influent to $520 \mathrm{mg} / 1$ for 3 days detention period, from $520 \mathrm{mg} / 1$ to $530 \mathrm{mg} / 1$ for 6 days detention period and from $530 \mathrm{mg} / 1$ to $610 \mathrm{mg} / 1$ for 9 days detention period. This is attributed to the production of algae in the baffled facultative pond. During the 12,15, 18, 21, 2427 and 30 days detention periods there is a reduction in the Total Dissolved Solids contents in the baffled facultative pond when compared with the influent, reducing from $508 \mathrm{mg} / 1$ to $500 \mathrm{mg} / 1$ for 12 days, from $500 \mathrm{mg} / 1$ to $402 \mathrm{mg} / 1$ for 15 days, from $402 \mathrm{mg} / 1$ to $220 \mathrm{mg} / 1$ for 18 days, from $220 \mathrm{mg} / 1$ to $178 \mathrm{mg} / 1$ for 21 days, from $178 \mathrm{mg} / 1$ to $82 \mathrm{mg} / 1$ for 24 days, from $82 \mathrm{mg} / \mathrm{l}$ to $71 \mathrm{mg} / 1$ for 27 days and from $71 \mathrm{mg} / 1$ to $56 \mathrm{mg} / 1$ for 30 days detention periods respectively. This is because there is a noticeable decline in the algae population during this period, due to the accumulation of solids in the pond. This made it difficult for the light to penetrate and hence photosynthesis was interfered.

The baffled facultative pond has an overall efficiency removal of $1.57 \%, 20.87 \%$, $65.69 \%, 83.86 \%, 86.02 \%$ and $88.98 \%$ for $12,15,18,21,24,27$ and 30 days detention periods respectively.

The overall performance of the baffled facultative pond was $88.98 \%$, the efficiency was better in the 30 days detention period.

\section{pH content}

Table 6. shows the $\mathrm{pH}$ content of the stabilized periods.

\begin{tabular}{|c|c|c|c|c|c|c|c|c|c|c|c|}
\hline $\begin{array}{c}\text { Influent time } \\
\text { (days) }\end{array}$ & 0 & 3 & 6 & 9 & 12 & 15 & 18 & 21 & 24 & 27 & 30 \\
\hline $\mathrm{pH}$ average & 6.5 & 6.0 & 6.1 & 7.3 & 6.7 & 6.9 & 7.06 & 7.1 & 7.18 & 7.21 & 7.23 \\
\hline
\end{tabular}


From the results of $\mathrm{pH}$ for stabilized effluent it can be seen that the baffled facultative pond maintained $\mathrm{pH}$ between 6.8 and 7.23 with 6.5 in the influent, 6.0 for 3 days, 6.1 for 6 days, 7.3 for 9 days, 6.7 for 12 days, 6.9 for 15 days, 7.06 for 18 days, 7.1 for 21 days, 7.18 for 24 days, 7.21 for 27 days and 7.23 for 30 days detention periods respectively. The $\mathrm{pH}$ values are between 6.5 and 7.23 which is suitable for bacteria growth. (6.5 to 8.5) Mara, et al. (2004)

\section{Alkalinity content}

Table 7 shows the results of Alkalinity of stabilized eft1uent. The Alkalinity of water has little significance, water with $\mathrm{pH}$ greater than 7 are said to be Alkaline. The Alkalinity test was also performed according to standard methods. It can be seen from the table that Alkalinity increases with increase in the detention period. From the results the Alkalinity varies from $28 \mathrm{mg} / \mathrm{l}$ in the influent to $26 \mathrm{mg} / 1$ for 3 days, $22 \mathrm{mg} / I$ for 6 days, $27 \mathrm{mg} / \mathrm{I}$ for 9 days, $29 \mathrm{mglI}$ for 12 days, $30 \mathrm{mglI}$ for 15 days, $31 \mathrm{mgll}$ for 18 days, $33 \mathrm{mg} / \mathrm{l}$ for 21 days, $33.5 \mathrm{mg} / \mathrm{l}$ for 24 days, $34 \mathrm{mg} / 1$ for 27 days and $35 \mathrm{mg} / 1$ for 30 days detention periods respectively.

Table 7. Alkalinity results

\begin{tabular}{|c|c|c|c|c|c|c|c|c|c|c|c|}
\hline $\begin{array}{c}\text { Detention } \\
\text { time (days) }\end{array}$ & Influent & 3 & 6 & 9 & 12 & 15 & 18 & 21 & 24 & 27 & 30 \\
days & days & days & days & days & days & days & days & days & days \\
\hline $\begin{array}{c}\text { Alkalinity } \\
(\mathrm{mg} / \mathrm{l})\end{array}$ & 28 & 26 & 22 & 27 & 29 & 30 & 31 & 33 & 33.5 & 34 & 35 \\
\hline
\end{tabular}

\section{Bacterial Removal}

Table 8 shows that the baffled facultative pond connected in series to the influent tank one side and the effluent tank the other side eliminated coliform bacteria from the wastewater up to $90 \%, 91 \%, 94 \%, 95 \%, 99.75 \%, 9.9 .98 \%$ and $99.98 \%$ for $12,15,18,21,2427$ and 30 days detention periods respectively. The inability of the pond to totally remove all coliform bacteria up to $99.99 \%$ may be due to coliform bacteria re-growth, some coliform bacteria can thrive and multiply at temperature above $15{ }^{\circ} \mathrm{C}$, and the laboratory where this research was carried out had an average temperature of 26 degree $C$. Hence the atmosphere was quite conductive for the bacteria to thrive and re-grow.( Nwigw, 2002)

Table 8. Bacterial removal results (stabilized efl1uent values)

\begin{tabular}{|c|c|c|c|c|c|c|c|c|c|c|c|}
\hline $\begin{array}{c}\text { Detention time } \\
\text { (days) }\end{array}$ & Influent & 3 & 6 & 9 & 12 & 15 & 18 & 21 & 24 & 27 & 30 \\
days & days & days & days & days & days & days & days & days & days \\
\hline$\%$ removal (\%) & $0 \%$ & - & - & - & $90 \%$ & $91 \%$ & $94 \%$ & $95 \%$ & 99.7 & $99.98 \%$ & $99.98 \%$ \\
\hline
\end{tabular}




\section{Chlorophyll 'A' content}

Table 9 shows the content of chlorophyll "A" in the baffled facultative pond and in the effluent. Chlorophyll " $A$ " is a common indicator of phytoplankton biomass. Chlorophyll "A" is used as an algal biomass indicator, ail green plants contain chlorophyll «A", the samples use for this experiment were taken every 3 days of running the experiment. It was stored for about ten days in a dark room, before the chlorophyll "A" test was carried out. It is obvious from the results that the chlorophyll content is decreasing with increase in detention period.

The values varies from $580.16 \mathrm{mg} / \mathrm{L}$ in the influent to $315.92 \mathrm{mg} / \mathrm{L}$ for 3 days, $243.52 \mathrm{mg} / \mathrm{lm}^{3}$ for 6 days, $208.47 \mathrm{mg} / \mathrm{L}$ for 9 days, $200.12 \mathrm{mg} / \mathrm{L}$ for 12 days, 158. $\mathrm{mg} / \mathrm{L}$ for 15 days, $112.15 \mathrm{mg} / \mathrm{L}$ for 18 days, $81.00 \mathrm{mg} / \mathrm{L}$ for 21 days, $53.03 \mathrm{mg} / \mathrm{L}$ for 24 days, $22.34 \mathrm{mg} / \mathrm{L}$ for 27 days and $19.72 \mathrm{mg} / \mathrm{L}$ for 30 days detention periods respectively.

This chlorophyll "A" reduction may be caused by the lack of light during some period of the day, because the pond has not been supplied with light for 24 hours every day.

Table 9. Chlorophyll "A" results (stabilized efl1uent values)

\begin{tabular}{|l|c|c|c|c|c|c|c|c|c|c|c|}
\hline $\begin{array}{l}\text { Detention } \\
\text { time (day) }\end{array}$ & Influent & 3 & 6 & 9 & 12 & 15 & 18 & 21 & 24 & 27 & 30 \\
\hline $\begin{array}{l}\text { Chlorophyll } \\
\text { "A" (mg/l) }\end{array}$ & 580.16 & 315.92 & 243.52 & 208,47 & 200.12 & 158.77 & 112.15 & 81.00 & 53.03 & 22.34 & 19.72 \\
\hline
\end{tabular}

\section{CONCLUSION}

The treatment of wastewaters by the use of a single baffled facultative pond gives an appreciable result. The BOD efficiency removal in the baffled facultative pond was $6.45 \%, 32.26 \%, 41.92 \%, 61.29 \%, 70.97 \%, 75.48 \%, 82.58 \%, 89.68 \%, 94.190 / 0$ and $96.13 \%$ for $3,6,9,12,15,18,21,24,27$ and 30 days detention periods respectively which is better than the result in the figure on table 1 for a plain facultative pond (removal between $50 \%$ and $70 \%$ ). The baffled facultative pond was able to eliminate about $99.98 \%$ of total coliform bacteria. The $\mathrm{pH}$ value was between 6.5 and 7.23 which is suitable for bacteria growth. (6.5 to 8.5). 5) The efficiency depends to a great extent on the detention period. The higher the detention period, better the effluent. A linear relationship existed between the BOD and the COD of the Dairy wastewater. As the detention period increases, the BOD and the dissolved oxygen (DO) decrease. It means that the BOD is linearly related to the dissolved oxygen. The provision of light for 24 hours is very important in the treatment of Dairy wastewater using baffled facultative pond because of the chlorophyll "A" content in 
the wastewater. According to this pilot study bio-degradable organic materials from dairy waste can be effectively removed by baffled facultative stabilization pond. The laboratory study which was carried out on a wastewater from yoghurt production justifies it. The total dissolved solids efficiency removal in the baffled facultative pond was $1.57 \%, 20.87 \%, 56.69 \%, 64.96 \%, 83.86 \%, 86.02 \%$ and $88.98 \%$ for $12,15,18$, $21,24,27$ and 30 days detention periods respectively. The overall performance of the pond is $88.98 \%$, the efficient was better in the 30 days detention period.

\section{REFERENCES}

1. Kareen, A. L. 2002. The performance of facultative waste stabilization pond in the United Kingdom. Ph.D. Thesis, University of Leeds, U.K.

2. American Public Health Association (APHA) 1998. Standard method for the examination of waste water $16^{\text {th }}$ edition.

3. Horan, N.J. 2003. Biological waste treatment system, theory and operation. John Wiley and Sons. New York.

4. Mara, P., K. Sholomo, and A. Timori. 2004. Sewage treatment in hot climates. John Wiley publications, ISBN: 987-85-502321-8, London

5. Najafpour, G.D., B.A. Hashemiyeh, M. Asadi and M.B. Ghasemi. 2008. Biological Treatment of Dairy Wastewater in an Up flow Anaerobic Sludge-Fixed Film Bioreactor. American-Eurasian J. Agric. \& Environ. Sci., 4 (2): 251-257, ISSN 1818-6769

6. Nwigwe N.E. 2002. The treatment of poultry waste by means of wastewater stabilization ponds. Proceeding of $30^{\text {th }}$ industrial waste conference. May $6^{\text {th }}, 7^{\text {th }}$ and $8^{\text {th }}$ 2002. Ann Arbor Science publisher Inc.

7. Ozoukwu E. 2004. Seminar aspect on small scale milk processing. Dairy Research program NAPRI, A.B.U, Shika, Zaria.

8. Ramadan, H. and Ponce V. M. 2006. Design and performance of waste stabilization ponds. IRC International Water and Sanitation Centre.

9. Varon, K.d. and P. K. Mara. 2010. Treatment of Liquid waste using anaerobic waste stabilization ponds. Waste stabilization technology and application, Elsevier science,

3 (4). 
تصميم انثاء حوض ترسيب و معالجة المخلفات السائلة لمصانع الالبان

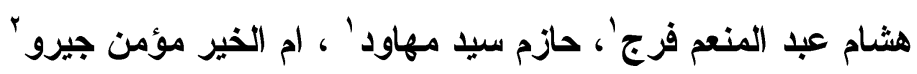

$$
\begin{aligned}
& \text { أمعز بحوث الهندسة الزراعية - مصر }
\end{aligned}
$$

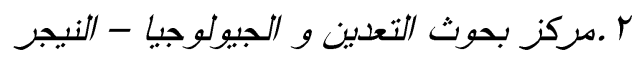

تم تصميم و انشاء حوض او بركة صناعية لمعالجة المخلفات السائلة الناتجة من تصنيع منتجات الالبان والتى تم تجميعها من مشروع بحثى لتربية الابقار الحلابة و تصنيع اللبن الزبادى و

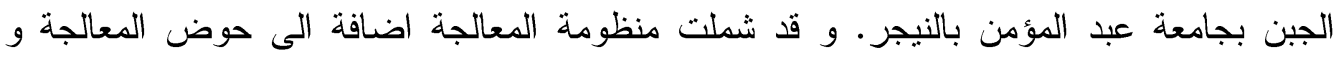
التتقية الرئيسي حوضا للتخزين. و تم تحميل حوض المعالجة لفترات من ثلاث الى ثلاثيين يوما.

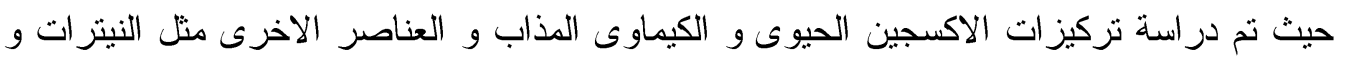

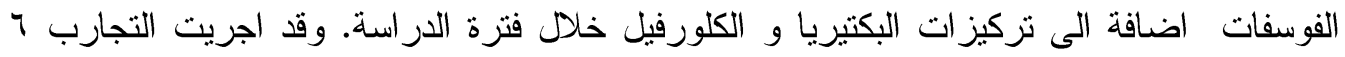

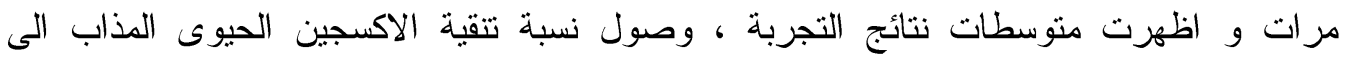

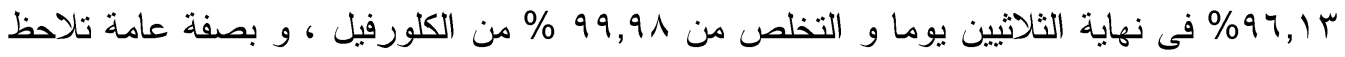
علاقة طردية بين الاكسجين الحيوى و الكيماوى المذاب و بين الاكسجين الحيوىو الاكسجين المذاب الكلى مع فترة التنقية للمخلفات السائلة. 